\title{
Tipologi Ketertinggalan Desa di Kabupaten Situbondo dengan Analisis Kluster pada ArcGIS dan Excel
}

\author{
Luqman Raharjo dan Arwi Yudhi Koswara \\ Perencanaan Wilayah dan Kota, Fakultas Arsitektur, Desain dan Perencanaan \\ Institut Teknologi Sepuluh Nopember (ITS) \\ e-mail: apitimur@yahoo.co.id, arwiyudhi@gmail.com
}

\begin{abstract}
Abstrak-Permasalahan ketertinggalan suatu daerah dapat dilihat dari beberapa indikator, diantaranya adalah sarana dan prasarana, perekonomian masyarakat, sumber daya manusia, dan kelembagaan. Kabupaten Situbondo merupakan salah satu potret daerah tertinggal di Provinsi Jawa Timur yang ditetapkan oleh Kementerian Desa, Daerah Tertinggal, dan Transmigrasi. Jumlah desa tertinggal di Kabupaten Situbondo tidak mengalami perubahan kuantitas dalam rentang waktu antara 2004 hingga 2015, yakni berjumlah 12 desa. Penelitian untuk menentukan tipologi ketertinggalan desa di Kabupaten Situbondo mendesak untuk dilakukan. Penelitian ini mengkuantifikasi data-data dari 4 indikator yang berisikan 13 variabel dengan analisis kluster melalui perangkat lunak Excel dan ArcGIS untuk memudahkan pembacaan kondisi ketertinggalan desa melalui peta. Penulis menetapkan jumlah kluster (tipologi) sejumlah 3 kluster. Analisis kluster dimulai dari variabel-variabel untuk menemukan rentang ketertinggalan per variabel. Hasil dari analisis kluster per variabel digabungkan untuk menentukan ketertinggalan per desa sehingga dapat membentuk tipologi ketertinggalan desa. Terdapat tiga tipologi ketertinggalan desa di Kabupaten Situbondo, yaitu tipologi 1, sangat tertinggal, berisikan 4 desa dengan tingkat ketertinggalan parah pada aspek sarana dan prasarana dasar dan menengah pada aspek perekonomian masyarakat, sumber daya manusia, dan kelembagaan. Tipologi 2, moderat, berisikan 6 desa dengan tingkat ketertinggalan menengah pada sarana dan prasarana dasar serta perekonomian masyarakat dan kelembagaan serta ringan pada sumber daya manusia. Tipologi 3, berpotensi maju, berisikan 2 desa dengan tingkat ketertinggalan menengah pada sarana dan prasarana dasar dan perekonomian masyarakat, serta ringan pada sumber daya manusia dan kelembagaan.
\end{abstract}

Kata Kunci-Analisis kluster, ArcGIS, desa tertinggal, tipologi.

\section{PENDAHULUAN}

$\mathrm{K}$ ESENJANGAN antar daerah merupakan salah satu isu kebijakan yang sejak lama menjadi perhatian pemerintah, terutama sejak dibentuknya Menteri Negara Pembangunan Daerah Tertinggal pada tahun 2004. Kesenjangan antar daerah terjadi terutama antara perdesaan dengan perkotaan, antara Jawa dengan luar Jawa, antara kawasan hinterland dengan kawasan perbatasan, serta Kawasan Barat Indonesia dengan Kawasan Timur Indonesia [1].

Untuk mengetahui ketertinggalan suatu daerah, Kementerian Desa, Pembangunan Daerah Tertinggal, dan Transmigrasi (Kemendes PDTT) Republik Indonesia merumuskan enam kriteria untuk mengukur maju atau tertinggalnya suatu daerah, yaitu perekonomian masyarakat, sumber daya manusia, sarana dan prasarana, kemampuan keuangan daerah, aksesibilitas, dan karakteristik daerah. Dari enam kriteria tersebut, Kemendes PDTT pada tahun 2015 menyebutkan ada 122 kabupaten di Indonesia yang masuk dalam kategori daerah tertinggal [2]. Di Jawa Timur ada empat kabupaten yang masuk dalam kategori daerah tertinggal. Salah satunya adalah Kabupaten Situbondo. Hal ini dapat dibuktikan berdasarkan 3 dari 6 kriteria yang dirumuskan Kemendes PDTT. Apabila ditinjau dari sisi perekonomian masyarakat, maka Kabupaten Situbondo memiliki 43,87\% atau 292.198 jiwa dari penduduknya dikategorikan penduduk miskin, berada di atas rerata penduduk miskin di Jawa Timur, yakni 12,28\%. Apabila ditinjau dari sumber daya manusia, penduduknya memiliki rata-rata lama sekolah 5,54 tahun dari seharusnya wajib belajar 12 tahun. Apabila ditinjau dari sisi sarana dan prasarana, jumlah SMP di Kabupaten Situbondo sebanyak 97 unit [3], sementara kebutuhan minimalnya apabila dilihat dari jumlah penduduknya adalah 139 sekolah [4].

Pada tahun 2015 Kemendes PDTT menerbitkan buku Data dan Peta Sebaran desa di 122 daerah tertinggal. Desa tertinggal yang ada di Kabupaten Situbondo berjumlah 12 desa [5]. Penelitian sebelumnya mengenai desa tertinggal di Indonesia pada tahun 2004 menyebutkan bahwa desa tertinggal di Kabupaten Situbondo berjumlah 12 desa [6]. Hal ini menandakan pembangunan desa tertinggal di Kabupaten Situbondo tidak memiliki kemajuan yang signifikan sehingga perlu diadakan penelitian untuk menentukan tipologi ketertinggalan desa di Kabupaten Situbondo.

Daerah tertinggal merupakan daerah yang memiliki ketergantungan besar terhadap daerah di luarnya karena pembangunan ekonomi di daerah tersebut terhambat karena rendahnya kualitas sumber daya manusia yang disebabkan karena kekurangan sarana dan prasarana dasar [7]. Sementara tipologi dalam ilmu humaniora diartikan sebagai ilmu watak tentang bagian manusia dalam golongan-golongan menurut corak watak masing-masing [8]. Dapat dikatakan pula merupakan studi atau analisis atau klasifikasi kumpulan informasi berdasarkan kedekatan jenis maupun kategori. Tipologi desa yang dimaksudkan di sini adalah tipologi desa tertinggal yang berarti pengelompokan ketertinggalan desa. Pengelompokan ketertinggalan desa akan dilakukan berdasarkan indikator-indikator ketertinggalan desa. 


\section{METODE PENELITIAN}

\section{A. Jenis dan Pendekatan Penelitian}

Pendekatan yang digunakan dalam penelitian ini adalah pendekatan rasionalistik. [9] Jenis penelitian dalam penelitian ini adalah deskriptif kuantitatif dan kualitatif.

\section{B. Variabel Penelitian}

Penelitian ini menggunakan 4 aspek, yakni sarana dan prasarana, perekonomian masyarakat, sumber daya manusia [10], dan kelembagaan dengan penjabaran variabel penelitian berupa jalan utama, telekomunikasi, listrik, air bersih, sarana pendidikan, sarana perdagangan, tingkat kemiskinan, produksi pangan, lama waktu sekolah, angka melek huruf, lembaga keuangan mikro, dan balai ekonomi desa.

\section{Pengumpulan Data}

Data-data dalam penelitian ini bersumber dari survei instansi dan studi literatur sebagai data dasar yang diperkaya dengan observasi lapangan serta wawancara untuk memeperdalam informasi terkait desa tertinggal di Kabupaten Situbondo. Wawancara juga digunakan untuk melengkapi data-data yang tidak didapatkan dari survei instansi maupun studi literatur.

\section{Menganalisis Tipologi Ketertinggalan Desa di Kabupaten} Situbondo menggunakan Analisis Kluster

Analisis kluster menghasilkan pengelompokan desa-desa tertinggal dengan tiga tipologi, yakni tipologi 1, tipologi 2, dan tipologi 3. Penulis menggunakan software ArcGIS dan Excel untuk analisis kluster karena hasil pengelompokan melalui ArcGIS dapat langsung dipetakan pada peta, sedangkan Excel dibutuhkan untuk proses perhitungan hasil dari kluster dan pembuatan matriks ketertinggalan desa. Langkah-langkah dari analisis kluster menggunakan ArcGIS adalah sebagai berikut:

1. Pastikan data pada masing-masing variabel tercantum pada "Attribute table"

2. Masuk ke "Properties" dari shape file peta, pilih "Symbology"

3. Pada "Show", pilih "Graduated colors" dari "Quantity"

4. Pada "Fields" bagian "Value", pilih variabel yang ingin dikelompokkan dan ditampilkan pada peta.

5. Pada "Classification", klik "Classifiy"

6. Pada "Classification", pilih "Equal Interval" dari "Method", lalu pilih 3 pada "Classes" lalu klik "Exclusion"

7. Pada "Data Exclusion Properties", ketik variabel yang akan ditampilkan dari kolom "SELECT * FROM", tambahkan "= 0 " untuk menghindari tampilnya desa-desa diluar desa tertinggal. Legenda dari exclusion bisa diberi warna sesuai keinginan.

8. Klik OK tiga kali

Setelah seluruh variabel telah melalui analisis kluster, hasil analisis tersebut direkapitulasi ke matriks ketertinggalan desa dengan menggunakan software Excel.

Analisis kluster dapat juga dilakukan menggunakan pelajaran statistik dasar. Nilai kluster didapatkan dari selisih nilai tertinggi dengan nilai terendah dibagai dengan jumlah kluster (tipologi) yang diinginkan.

$$
\begin{aligned}
& K=\frac{\max -(\min -1)}{n} \\
& \text { - } K \quad=\text { jarak kluster } \\
& \text { - } \max =\text { nilai maksimal } \\
& \text { - } \min =\text { nilai minimal } \\
& \text { - } n \quad=\text { jumlah kluster yang diinginkan }
\end{aligned}
$$

Apabila nilai $K$ telah didapatkan, maka $K$ tersebut memiliki indeks sejumlah $n$. Misal nilai $n$ adalah 3, maka $K_{1}$ merupakan kluster pertama, $K_{2}$ merupakan kluster kedua, dan $K_{3}$ merupakan kluster ketiga. Perhitungan matematisnya adalah sebagai berikut:

$$
K_{n}=(\min -1)+K * n
$$

\section{HASIL DAN DISKUSI}

\section{A. Analisis Tipologi Ketertinggalan Desa per Variabel di Kabupaten Situbondo}

Tipologi desa tertinggal diawali dengan membuat tipologi tiap variabel untuk mempermudah pemahaman kondisi ketertinggalan desa. Tipologi ketertinggalan desa dibagi menjadi 3 kelompok:

a. Tipologi 1, relatif sangat tertinggal;

b. Tipologi 2, relatif moderat; dan

c. Tipologi 3 , relatif berpotensi maju.

Tingkatan dalam tipologi per variabel diberi nilai 1-3 sesuai

\begin{tabular}{|c|c|c|c|c|}
\hline \multirow{2}{*}{ No. } & \multirow{2}{*}{ Variabel } & \multicolumn{3}{|c|}{ Representasi Nilai } \\
\hline & & 1 & 2 & 3 \\
\hline \multirow{2}{*}{1} & \multirow{2}{*}{ Jalan Utama } & $14,8-35,7 \%$ & $35,71-56,61$ & $56,62-77,52$ \\
\hline & & Baik & $\%$ Baik & $\%$ Baik \\
\hline \multirow{2}{*}{2} & \multirow{2}{*}{ Listrik } & $67-77,9 \%$ & $77,91-88,81$ & $88,82-99,72$ \\
\hline & & Teraliri & $\%$ Teraliri & $\%$ Teraliri \\
\hline \multirow{2}{*}{3} & \multirow{2}{*}{ Air Bersih } & $61,5-74,33 \%$ & $74,34-87,16$ & $87,17-100 \%$ \\
\hline & & Teraliri & $\%$ Teraliri & Teraliri \\
\hline \multirow{2}{*}{4} & \multirow{2}{*}{ Telekomunikasi } & Susah & \multirow{2}{*}{ Moderat } & Mudah \\
\hline & & Terjangkau & & Terjangkau \\
\hline \multirow{3}{*}{5} & Sarana & & & \\
\hline & $\begin{array}{l}\text { Pendidikan } \\
\text { (SD) }\end{array}$ & 1-2 SD & $3 \mathrm{SD}$ & $4 \mathrm{SD}$ \\
\hline & Sarana & & & \\
\hline 6 & $\begin{array}{l}\text { Pendidikan (SMP } \\
\text { per Kecamatan) }\end{array}$ & 4-6 SMP & 7-9 SMP & 10-11 SMP \\
\hline \multirow{2}{*}{7} & Sarana & $10-19$ & $20-29$ & $30-38$ \\
\hline & Perdagangan & Peracangan & Peracangan & Peracangan \\
\hline \multirow[b]{2}{*}{8} & Produksi & $0,1-2,04$ & $2,05-3,93$ & $3,94-5,87$ \\
\hline & Pangan & $\begin{array}{l}\text { milyar } \\
\text { Rupiah }\end{array}$ & milyar Rupiah & milyar \\
\hline \multirow[b]{2}{*}{9} & Tingkat & $57,28-73,06$ & $41,5-57,27 \%$ & $25,7-41,49 \%$ \\
\hline & Kemiskinan & $\%$ Miskin & Miskin & Miskin \\
\hline \multirow{2}{*}{10} & Lama Waktu & $3,8-5,41$ & $5,42-6,98$ & $6,99-8,55$ \\
\hline & Sekolah & Tahun & Tahun & Tahun \\
\hline 11 & $\begin{array}{l}\text { Tingkat Melek } \\
\text { Huruf }\end{array}$ & $\begin{array}{l}38,25-56,76 \\
\% \text { Melek } \\
\text { Huruf }\end{array}$ & $\begin{array}{l}56,77-75,28 \\
\% \text { Melek } \\
\text { Huruf }\end{array}$ & $\begin{array}{l}75,29-93,8 \% \\
\text { Melek Huruf }\end{array}$ \\
\hline \multirow{2}{*}{12} & Tingkat & $14,17-21,17$ & $7,17-14,16 \%$ & $0,16-7,16 \%$ \\
\hline & Pengangguran & $\begin{array}{l}\% \\
\text { Menganggur }\end{array}$ & Menganggur & Menganggur \\
\hline 13 & $\begin{array}{l}\text { Lembaga } \\
\text { Keuangan Mikro }\end{array}$ & Tidak Ada & Baru & Ada \\
\hline
\end{tabular}
dengan tingkatannya. Berikut adalah representasi nilai dari masing-masing tingkatan per variabel hasil analisis kluster per variabel.

Tabel 1

Penilaian Tingkatan Tipologi per Variabel 


\section{B. Analisis Tipologi Ketertinggalan Desa di Kabupaten Situbondo}

Setelah masing-masing tingkatan tipologi tiap variabel diberi nilai, hasil kuantifikasi tipologi tersebut digunakan untuk menilai seberapa tertinggalnya suatu desa. Penilaian tersebut dituangkan menjadi matriks ketertinggalan desa sebagaimana tabel berikut ini.

Tabel 2

Nilai Tipologi per Variabel Terhadap Desa Tertinggal di Kabupaten Situbondo

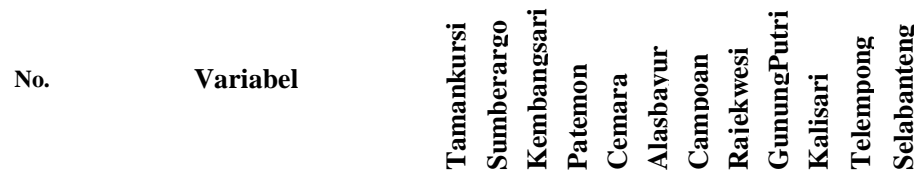

\begin{tabular}{|c|c|c|c|c|c|c|c|c|c|c|c|c|c|}
\hline 1 & Jalan Utama & 1 & 3 & 1 & 1 & 3 & 1 & 2 & 2 & 1 & 3 & 3 & 3 \\
\hline 2 & Listrik & 1 & 2 & 3 & 1 & 3 & 1 & 3 & 3 & 3 & 3 & 3 & 3 \\
\hline 3 & Air Bersih & 3 & 3 & 3 & 3 & 1 & 3 & 1 & 1 & 3 & 3 & 3 & 2 \\
\hline 4 & Telekomunikasi & 1 & 1 & 2 & 1 & 2 & 1 & 3 & 1 & 2 & 2 & 2 & 2 \\
\hline 5 & Jumlah SD & 1 & 1 & 2 & 2 & 1 & 1 & 2 & 2 & 3 & 1 & 1 & 1 \\
\hline 6 & Jumlah SMP per Kecamatan & 1 & 1 & 1 & 1 & 3 & 2 & 2 & 1 & 3 & 1 & 1 & 1 \\
\hline 7 & Sarana Perdagangan & 1 & 1 & 2 & 2 & 2 & 1 & 3 & 3 & 3 & 1 & 2 & 3 \\
\hline 8 & Tingkat Kemiskinan & 3 & 3 & 3 & 3 & 3 & 3 & 3 & 3 & 1 & 3 & 2 & 3 \\
\hline 9 & Produksi Pangan & 2 & 1 & 2 & 2 & 2 & 1 & 1 & 2 & 1 & 3 & 1 & 3 \\
\hline 10 & Lama Waktu Sekolah & 2 & 2 & 3 & 2 & 2 & 1 & 2 & 2 & 2 & 2 & 3 & 3 \\
\hline 11 & Angka Melek Huruf & 3 & 3 & 1 & 2 & 2 & 2 & 3 & 1 & 1 & 3 & 3 & 3 \\
\hline 12 & Tingkat Pengangguran & 3 & 3 & 3 & 3 & 3 & 3 & 2 & 3 & 1 & 3 & 3 & 3 \\
\hline 13 & Lembaga Keuangan Mikro & 3 & 3 & 2 & 1 & 1 & 3 & 3 & 1 & 3 & 1 & 1 & 3 \\
\hline
\end{tabular}

Setelah mengetahui nilai total ketertinggalan desa, analisis kluster kembali dilakukan untuk menentukan desa-desa tertinggal berdasarkan tipologi secara umum, yakni (1) sangat tertinggal, (2) moderat, dan (3) berpotensi maju. Analisis kluster menggunakan software ArcGIS agar langsung disajikan dalam bentuk peta untuk memudahkan pembacaan. Value yang digunakan untuk analisis kluster menggunakan ArcGIS adalah "Total Nilai" pada matriks ketertinggalan desa. Berikut adalah hasil dari tipologi seluruh variabel, disajikan dalam bentuk peta.

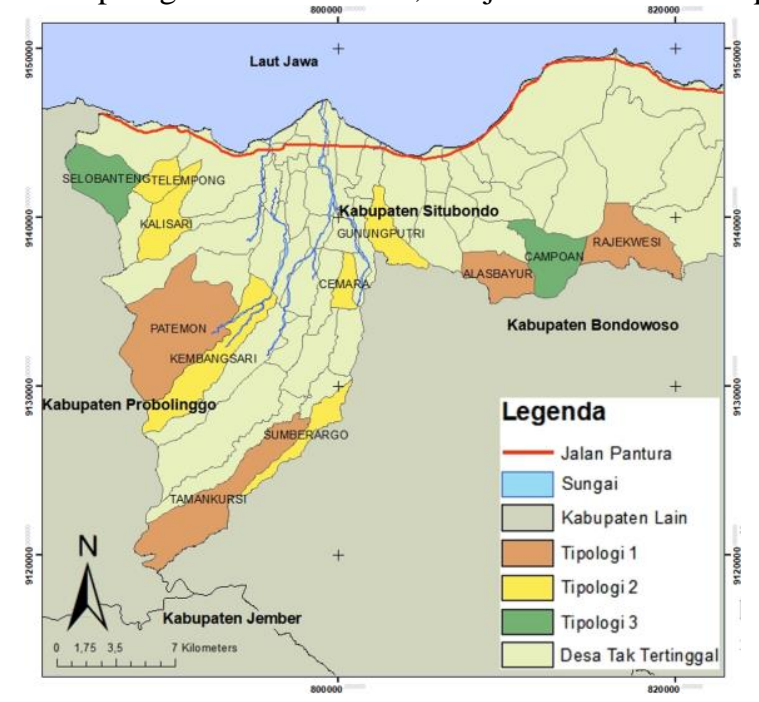

Gambar 1. Peta Tipologi Ketertinggalan Desa di Kabupaten Situbondo

Berdasarkan peta di atas, tipologi ketertinggalan desa di Kabupaten Situbondo adalah sebagai berikut:

a. Tipologi 1
1) Alasbayur
2) Patemon
3) Rajekwesi
4) Tamankursi

b. Tipologi 2
1) Sumberargo
2) Telempong
3) Cemara
4) Kembangsari
5) Kalisari
6) Gunung Putri

c. Tipologi 3

1) Campoan

2) Selabanteng

\section{KESIMPULAN}

Penelitian ini bertujuan untuk menentukan tipologi ketertinggalan desa di Kabupaten Situbondo berdasarkan aspek sarana dan prasarana, perekonomian masyarakat, sumber daya manusia, dan kelembagaan. Berikut adalah hasil dari proses penyusunan tipologi ketertinggalan desa di Kabupaten Situbondo:

Tipologi 1 adalah tipologi ketertinggalan desa dengan kondisi relatif sangat tertinggal di Kabupaten Situbondo. Tipologi 1 beriskan Desa Alasbayur, Desa Patemon, Desa Rajekwesi, dan Desa Taman Kursi dengan ciri ketertinggalan parah pada aspek sarana dan prasarana dasar dan menengah pada aspek perekonomian masyarakat, sumber daya manusia, dan kelembagaan.

Tipologi 2 adalah tipologi ketertinggalan desa dengan kondisi relatif moderat di Kabupaten Situbondo. Tipologi 2 beriskan Desa Sumber Argo, Desa Telempong, Desa Cemara, Desa Kembangsari, Desa Kalisari, dan Desa Gunung Putri dengan tingkat ketertinggalan menengah pada aspek sarana dan prasarana dasar, perekonomian masyarakat, dan kelembagaan serta ringan pada sumber daya manusia.

Tipologi 3 adalah tipologi ketertinggalan desa dengan kondisi relatif berpotensi maju di Kabupaten Situbondo. Tipologi 3 beriskan Desa Selabanteng dan Desa Campoan dengan tingkat ketertinggalan menengah pada aspek sarana dan prasarana dasar dan perekonomian masyarakat, serta ringan pada sumber daya manusia dan kelembagaan.

\section{DAFTAR PUSTAKA}

[3] B. P. Statistik, Kabupaten Situbondo Dalam Angka 2015. Situbondo: BPS Kabupaten Situbondo, 2015.

[4] B. S. Nasional, Tata cara perencanaan lingkungan perumahan di perkotaan. 2004.

[5] M. PDT, Keputusan Menteri Pembangunan Daerah Tertinggal No. 1 Tahun 2015 tentang Strategi Nasional Pembangunan Daerah Tertinggal. Jakarta, 2015.

[6] I. Agusta, Desa Tertinggal di Indonesia. Sodality: Jurnal 
Transdisiplin Sosiologi, Komunikasi, dan Ekologi Manusia. Bogor: IPB, 2007.

[7] R. Adisasmita, Dasar-dasar Ekonomi Wilayah. Yogyakarta: Graha Ilmu, 2005.

[8] P. Bahasa, Kamus Bahasa Indonesia. Jakarta: Departemen Pendidikan Nasional, 2008.

[9] P. . Sugiyono, Metode Penelitian Pendidikan (Pendekatan Kuantitatif, Kualitatif dan R\&D). Bandung: Alfabeta, 2006.

[10] A. . Puspasari, A. Koswara, "Arahan Pengembangan Desa Tertinggal di Kabupaten Situbondo Berdasarkan Aspek Sosial, Ekonomi, dan Infrastruktur,” 2016. 